\title{
EMPIRICAL STUDY OF INTANGIBLE ASSETS IN ROMANIAN MUNICIPALITIES
}

\author{
Ovidiu Constantin Bunget, Rodica Gabriela Blidisel, \\ Liliana Feleaga, Irimie Emil Popa
}

\section{Introduction}

Nowadays technology provides tools with enormous intangible benefits to entities. While the multitude changes in the economic world challenges the financial stability, the importance of the information disclosed becomes essential in order to be taken good decisions. It is widely recognized that a key driver in the new world is knowledge [3], [36].

Economic success is increasingly based on upon the effective utilization of intangible assets, but despite of their significance, the literature reveals a low level of interest in their identification, measurement and disclosure, especially in the public sector. Despite the interest of the private sector, public sector entities have made less effort in this way, which is to be regretted, since intangibility is more present in the public sector than in private sector. The literature points out arguments such as: multiple objectives of a non-financial nature, more intensive use of the intangible assets (especially related to human resources and knowledge), the services - essentially intangible, as the generally final product of public entities.

With the aim to improve the quality of financial reporting of public sector entities for a better informed judgment of the resource allocation decisions as well as an increasing transparency and accountability, the International Public Sector Accounting Standards (IPSAS) became the definitive set of accrual-based international accounting standards for the public sector. In the framework of our subject the International Public Sector Accounting Standard no. 31 [17] places the public entities under the obligation to recognize intangible assets in the balance sheet, complying with three critical attributes of identifiability, control and future economic benefits or service potential.

In spite of the accounting rules that establish generally accepted criteria regarding the measurement, recognition and disclosure of these intangible assets, the literature points out that subjective factors could come into play, permitting that their value to be manipulated easily, especially for so-called intellectual capital. Subjective measurement could generate bad information to stakeholders that is a significant problem. Besides the accounting approaches, the literature reveals both monetary and nonmonetary intangible assets measurement methods, developed during the time, most of them being transposed in the public sector from the private one, having the purpose a better internal decision making. Given the level of intangible assets trend development, the authors support the idea of three disclosure levels as regard the development stages in the process of measurement and recognition of full intangible assets.

Besides the costs and benefits of disclosing information about intangibles, a supplementary question could arrive as regards the determinants of intangible assets reporting.

At European level, according to the Lisbon Strategy, the management of knowledge and innovation represents a priority, intended to make the European Union the most competitive and dynamic economy in the world. Romania, as an European Member state, must comply with this strategy. In order to reduce the disparities between Romania and the other Member States, to have a regional development based on performance and better accountability, the Romanian government aligned to the European 
and international standards and implemented different reforms in public administration [28], [26], [29], [30]. Also, for a better decision making, the accounting system was reformed; in 2006 the Romanian public sector passed from a cash-based accounting system to an accrualbased accounting system [35] with identified elements of International Public Sector Accounting Standards regulation.

While there are few research papers in the literature in the field of intangible assets in public sector, especially in the local public administration, theoretical and empirical contributions of this paper are auspicious for the issues establishment and the state of knowledge in Romanian municipalities' awareness, transparency and disclosure of public information of general interest. The motivation is even greater as these aspects of intangible assets represent a subject of national and international debate. Transformations performed by the Romanian public administration in the process of regional development, particularities of human resources knowledge improvement once with these reforms, technical and informational system implemented to support the innovation gives us a particular research advantage compared to others in the relevant literature.

Generally, the wealth created by the knowledge and intangible resources is seen mostly in municipalities with a relatively large population and a major economic, social, political and cultural significance. In this respect our research occurs in time to find out the intangible assets disclosure level of all the Romanian municipalities.

Considering the identification, measurement and disclosure of intangible assets a stringent research problem, in the light of the theoretical evidences, we investigate the stage of intangible assets process developed by the Romanian municipalities as important catalysts of political and public visibility as well as promoters of information production, taking into account as main investigation items the awareness about intangible assets importance of the decision makers in these entities as well as the disclosure level and the most influential factors in this disclosure.

The research approaches at empirical level the knowledge of financial accounting department representatives from Romanian municipalities about the assets non physical in nature, the criteria for recognition and their importance of disclosure. While more and more municipalities are looking on New Public Management techniques which reflects the huge changes which have taken place in the last 15 years towards so called "knowledge economy", it is clear that information on intangible resources should be integrated in the decision-making process, improving the visibility and having as a result important competitive advantages.

The research is based on the content analysis technique, in order to find out if the annual reports of Romanian municipalities reflect, in their disclosed accounts, the recognized importance of intangible assets in today's economy and in the international accounting doctrine as well as if there are factors that influence this disclosure. Taking into account a dichotomist procedure based on disclosure and application/ /relevance observations, the results reveal the low disclosure of intangible assets according to the requirements of IPSAS 31 together with national standards. Size explained by the population number and the logarithm of assets are factors that influence the disclosure of intangible assets information.

Moreover, following in-depth semi-structured interviews, we found out the awareness of representatives of financial accounting department of Romanian municipalities as regards the identification, measurement and disclosure of intangible assets.

The paper starts by identifying the literature review in the field of intangible assets identification, measurement and disclosure, main theories being associated with this problem, followed by the definition of the dependent and independent variables selected. The structure continues with the results analysis: the descriptive statistics of the variables under study, followed by a by a multivariate analysis, with the intent to conclude the existence or not of a linear association between the disclosure index created and the explanatory variables considered in our study. We end by presenting our main conclusions.

\section{Literature Review}

\subsection{Features of Changing Catalyst in Public Sector}

Numerous changes in structure, financing, and services delivered by the public sector challenges 
it to face the risk that can arise. Therefore, the public sector should provide good analysis and reporting and encourage better use of information to support good decision-making.

In the reform process the public sector transposed approaches from the private sector, there were identified six dimensions: privatization, marketing, corporate management, regulation, decentralization and political control [40]. Public sector has been undertaken all these reforms to meet a number of objectives aiming at enhancing accountability, strengthening governance and increasing transparency. The most important feature of these reforms revolves around the relevance, efficiency and effectiveness of the public sector, linking the objectives with resources and outcomes.

The ongoing crisis in several countries around the world has demonstrated the challenges of maintaining financial stability and the importance of the information disclosed in order to make good decisions. Many governments are exploring the adoption of accrualbased accounting frameworks in order to improve their decision-making ability to prevent and respond to these challenges. International Public Sector Accounting Standards (IPSAS) are considered the definitive set of accrualbased international accounting standards for the public sector. They are issued by the IPSAS Board (IPSASB) for use by public sector entities around the world in the financial statements preparation, aiming to improve the quality of financial reporting general purpose, leading to better informed judgment of the resource allocation decisions, thereby increasing transparency and accountability. IPSASB adapted the private sector IFRS to the public sector context when appropriate, attempting, wherever possible, to maintain the accounting treatment and original text of the IFRS unless there is a significant public sector issue which warrants a departure.

But there are disparities between private and public sector, many of them arousing heated debates, being generated by:

1. the different conceptual framework, the private sector standards providing principles for certain economic phenomena that are irrelevant to the operations of public sector entities;

2. the prevalence of the non-exchange transactions within the public sector which emphasizes disputes as regards their measurement and recognition, the service potential being an important part of the definitions and recognition criteria;

3. comparison of the actual financial performance of an entity with the approved budget of that entity, where the budget is publicly available, with the increased focus on stewardship, service delivery and budget management in the public sector.

\subsection{Service Potential - a Parameter of Public Sector Assets}

Based on these disparities, the paper focuses on the special role of assets in public sector, those that are likely to be non-cash generating. Of these, in recent years, intangible assets have attracted most accounting-related debates.

Assets are the fundamental concept in accounting. Assets, also called economic resources, are the lifeblood of both business enterprises and not-for-profit organizations [14]. In the private sector the assets are important information due to their capacity to generate profits. The IASB gives the following definition: "An asset is a resource controlled by the entity as a result of past events and from which future economic benefits are expected to flow to the entity." We cannot say the same thing about public sector. Many of the assets of public sector entities are acquired or incurred as a result of the entity's service delivery mandate. Therefore, IPSAS introduces the concept of service potential as part of the definitions and recognition criteria. Service potential is also a supplementary recognition criterion to account for items that do not result in the inflow or outflow of economic benefits, where an item either contributes to or detract from the entity's ability to deliver its services [13].

IPSAS 1 describes an asset as "embodying service potential". According to IPSAS 1 the assets are "resources controlled by an entity as a result of past events and from which future economic benefits or service potential are expected to flow to the entity".

As regards this definition there are discussions on the IPSASB agenda, the respondents questioned sustaining that an asset do not necessarily delivers an inflow of service potential to the entity that holds it, considering that an asset is used by the entity to deliver an outflow of services to the public, suggesting the 
following definition: "An asset is a resource controlled by the entity as a result of past events, from which future economic benefits are expected to flow to the entity, or from which service potential is expected to be extracted by the entity in the future" [18].

Public entities frequently expend resources or incur liabilities on the acquisition, development, maintenance, or enhancement of important intangible resources such as organizing a world-wide event, scientific or technical knowledge improvement, development costs, design and implementation of new processes or systems, patents, copyrights, licences, intellectual property and trademarks (including brand names and publishing titles), computer software, motion picture films, lists of users of a service.

The $R \& D$ and the introduction of information technology in public services (e.g. municipality) may increase the citizen satisfaction, reducing queues in the provision of a service by allowing individuals to apply for it through the internet. The literature [7] points out the importance of identifying intangible assets, as they acknowledge their relevance in order to take better decisions and aim to prove to the public the performance as well as quality of management processes.

The importance of the information provided by financial statements as regards financial position, business performance and cash flows has never been questioned given that it is the basis for making rational economic decisions to a wide range of users, but the processes of globalization, internationalization and concentration of economic power replaced the traditional economy with the knowledge-based economy in which entities base their value generating and gaining a competitive advantage on intangible assets [24].

It is evident that intangible assets are both large and important, but current financial statements provide very little or no information about these assets and as a result, financial statements are incomplete, the information user not having accurate and complete knowledge about the intangibles owned and managed. [34]. The overwhelming importance attached to intangibles and any attempt to ignore them in financial reporting will lead to distortions and incomplete performance measurement [10]. Intangible assets are one of the components that must have adequate disclosure [20].
Many empirical studies on intangible assets in the private sector have now been published, but in contrast with the private sector, the identification, valuation and disclosure of intangible assets in the public sector is not very well developed. In this respect, there were identified three main characteristics of the public sector:

1. While private's sector main objectives are profitability and firm value, the public administrations have multiple objectives of a non-financial nature;

2. Even if both the public and the private sector use the same production inputs human resources, knowledge, money, raw materials, and plant - the public sector makes more intensive use of the first two, and these are intangible;

3. The final product of public administration is a service, and this is essentially intangible.

IPSAS 31 places the public organizations under an obligation to recognize intangible assets in balance sheet. According to IPSAS 31, paragraph 16, an intangible asset is an identifiable non-monetary asset without physical substance.

In public sector there could be identified different intangible assets, the regulation bodies offering examples for this purpose. Tab. 1 presents a comparison of intangible assets examples provided by Romanian regulations for public sector accounting and IPSAS.

We point out that in Romania, in the spirit of New Public Management philosophy, beginning with January 1st 2006, public sector institutions have realized the transition from cash accounting regulated since 1970 by Order of Public Finance Ministry no. 596 to accrual accounting regulated by the Order of Public Finance Ministry no.1917/2005 (referred to as OMFP 1917/2005 updated) for approving the Methodological Norms concerning the organization and conducting of public sector accounting, the Chart of accounts and the Instructions for applying it, being inspired from IPSAS provisions [6].

Also there are different examples, according to IPSAS 31 intangible assets have to comply with: identifiability, control (ability to obtain benefits from the asset) and future economic benefits or service potential (e.g. revenues or future costs decreasing). In order to fulfil these characteristics to satisfy the normal asset recognition criteria the intangible 
Tab. 1: Intangible assets classes provided by OMFP and IPSAS

\begin{tabular}{l|l} 
OMFP 1917/2005 updated & IPSAS $\mathbf{3 1}$ \\
\hline $\begin{array}{l}\text { Other intangible assets (computer software and other } \\
\text { intangible assets); }\end{array}$ & $\begin{array}{l}\text { Computer software; } \\
\text { Brand names; }\end{array}$ \\
\hline Licences; & Licences; \\
\hline $\begin{array}{l}\text { Concessions, patents, trademarks and } \\
\text { similar rights and assets; }\end{array}$ & $\begin{array}{l}\text { Copyrights, patents, and other industrial property rights, } \\
\text { service and operating rights; }\end{array}$ \\
\hline $\begin{array}{l}\text { Recordings of cultural and sports events such as: } \\
\text { theatrical, radio or television programs, musical works, } \\
\text { sporting events, literary, artistic or recreational recordings } \\
\text { made on film, magnetic tape or other media owned by the } \\
\text { institution, which are not subject to amortization; }\end{array}$ & $\begin{array}{l}\text { Recipes, formulae, models, designs, and prototypes; } \\
\text { Intangible assets under development. }\end{array}$ \\
\hline \begin{tabular}{l} 
Development costs. \\
\hline
\end{tabular} & \\
\hline
\end{tabular}

Source: own

assets meet difficulties. For this purpose, many value relevance studies are especially difficult to interpret in this area. For the USA private sector the AAA Financial Accounting Standards Committee, 2003 discusses the presence of a competitive market for assets; otherwise do not earn abnormal returns. The literature [19], [25], [1] raises the issue about the reliability and comparability of intangibles information, pointing out that there are also problems with choosing a measurement basis:

1. while using the cost as the measurement basis, it is difficult to know which costs relate solely to the acquisition of intangibles, when all aspects of the entity's operations affect an intangible like customer satisfaction and it is difficult to determine the portions of these costs that have future benefit;

2. while using the fair value as the measurement basis, we are a "long way" from being able to value many intangibles, such as customer satisfaction, given the many industry and competitive forces that affect intangibles' values.

\subsection{Intellectual Capital Models in the Public Sector}

One of the major assets of an organization is intellectual capital, since it promotes competitive advantages that are the base of value generation [11], [46], [22], [39].

The theory of intellectual capital has appeared in the past decade in response to the growing accomplishment of the importance of information and knowledge. Because it was first conceptualized during the same time period with the ideas of knowledge management and human capital, it became an important part of organizational discussion [16].

Although the intellectual capital concept was developed as a framework to analyze the contribution of intellectual resources of the private entities, due to its importance it was soon taken over by public and non-profit organizations [31], [23], [38]. The intellectual capital is the capacity it has to transform knowledge and intangible resources into wealth [4]. Moreover, the intellectual capital is distinguished as the value of the ideas generated by a human and structural capital which produces and shares knowledge [12].

In the knowledge era we can conclude that necessities like the demand of stakeholder for greater transparency, the increasing competition and greater autonomy push the municipalities towards the adoption of new reporting systems which should necessarily incorporate intangibles.

\subsection{Methods Developed for Measuring Intangible Assets besides the Accounting Approach}

In order to administrate the entity better, it is necessary to disclose the intangible assets into the financial statements and this idea is device as "If you don't measure, you can't administrate" [41]. However, it is denoted that this 
approach can be misleading. According to Intangible assets aren't less assets than the others [45], [49]. The rules of displaying intangible assets in financial statements must be the same as the other assets [44]. But since subjective factors come into play and there is a lack of generally accepted criteria at the measurement and evaluation of these intangible assets, this value can be manipulated easily. Subjective evaluation and measurement will generate bad information to stakeholders.

Parallel with accounting there were developed, especially for the private sector different intangible assets measurements to monitor performance (control), acquire/sell business (valuation), report to stakeholders, guide investments (decision), uncover hidden value (learning), divided into four main categories:
Direct Intellectual Capital Methods, Market Value Methods, Asset Return and Scorecard Methods. If the Intellectual Capital models applied easily in the private sector rely on the difference between the market value of the firm and its book value, in the public sector they should highlight how intangible assets are used to improve the quality of the services offered and their relevance for management. Fig. 1 shows the identified intangible assets measurement methods running in the public sector presented by the international literature, observing that in public sector prevails the nonmonetary valuation methods, especially scorecard methods which attempts to identify different components of intangible assets by means of indicators.

\section{Fig. 1: Intangible assets measurement methods within the public sector}

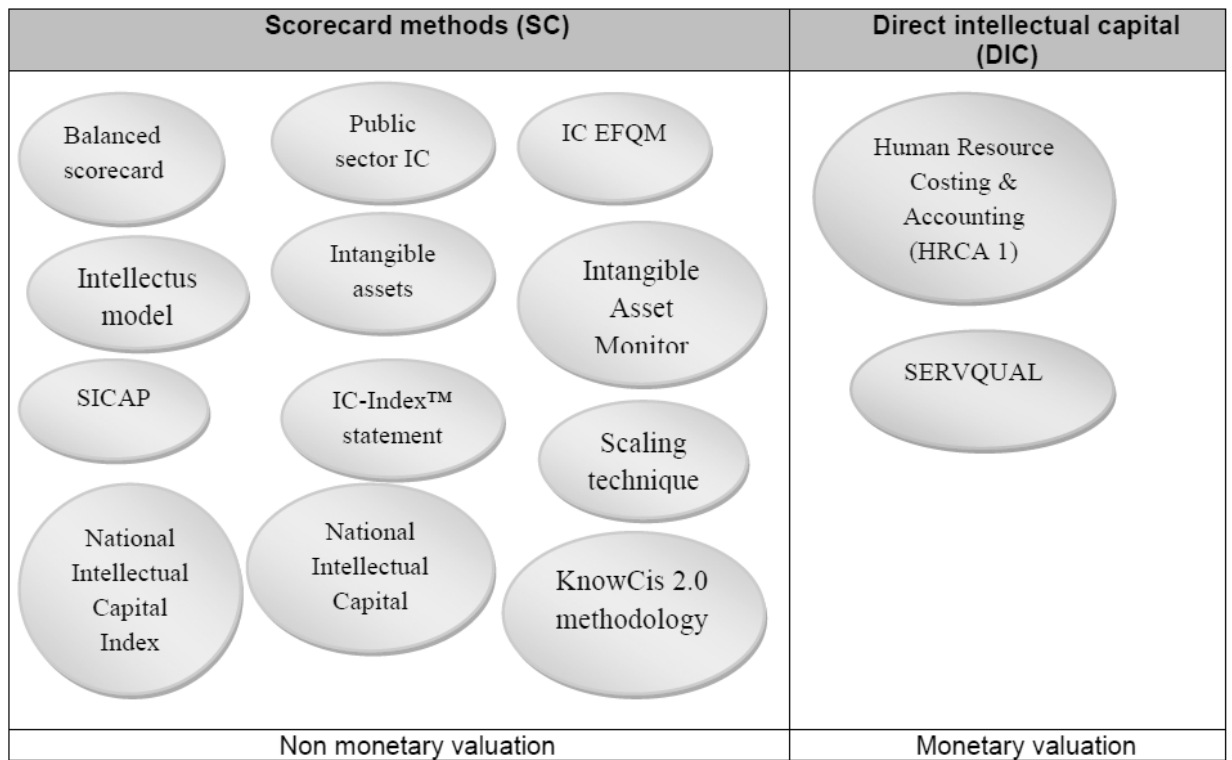

Source: own

More and more, once with the development of information and management systems in public sector there is a need that aim to estimate and control intangible capital as the main source of wealth creation [32]. But, on the other hand, the lack of competition within a monopolistic framework is far from an appropriate setting to stimulate the development of new practices in public sector. New Pubic Management requires the provision of good quality services and this might contribute to the development of intangible measurement in this context. Public sector entities have multiple objectives which are of an intangible nature. 


\section{Finance}

Moreover, services provided by public entities are intangible. The main resources of the public sector (e.g. human resources and knowledge) are intangible as well.

Having introduced the general framework for intangible assets in the public sector, the literature emphasizes the general consensus regarding the necessity to identify, to measure and to disclose the intangible assets held by each institution, while presently they are inadequately disclosed in traditional annual reports [42].

The literature reveals that some of intangibles were not being recognized on the Statement of Position in the public sector entities financial statements, providing alternatives to help the improvement of the intangible capital measurement and recognition. There is widely recognized that voluntary disclosures indicates that additional data about unrecognized intangible assets would be benefic because of the importance of intangibles. Also there are recommendations as regards disclosure rather than recognition of internally generated intangibles. This will lead to the reporting that reflect the qualities of relevance and reliability.

\section{Research Methodology and Data}

\subsection{Research Purpose and Objectives}

Before being found widely recognized ways of measuring and recognizing all the intangible assets that allow standardization of information, local governments must realize the purpose and benefits of the intellectual capital and to find indicators that characterize these intangible assets to be voluntarily disclosed. According to this statement and relating to benefits/ /costs on the one hand and to time/complexity/ integration on the other hand, in our opinion there are three disclosure levels as regard the development stages in the process of measurement and recognition of intangible assets in local public administration (Fig. 2):

Stage 1: Awareness about mandatory and voluntary disclosure, measurement and recognition;

Stage 2: Mandatory disclosure of intangible assets and characteristics related to voluntary disclosure of intellectual capital;

Stage 3: Full disclosure, measurement and recognition of all intangible assets (with full disclosed elements regarding intellectual capital).

\section{Fig. 2: Development stages in the process of measurement and recognition of intangible assets in local public administration}

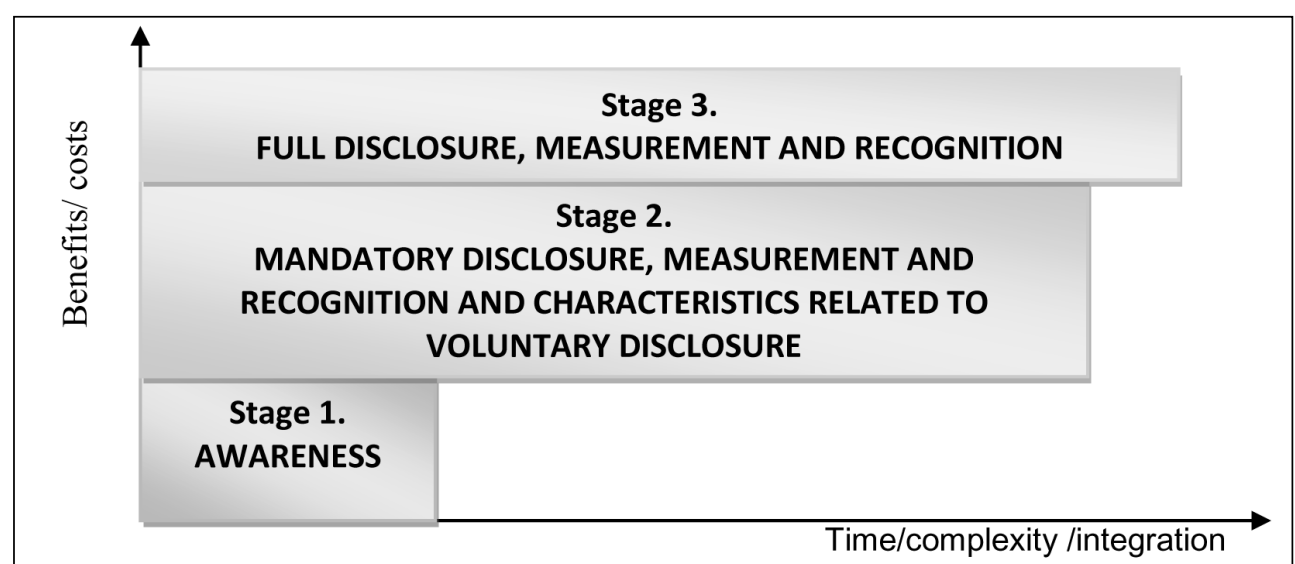


In the light of the theoretical evidences, the purpose of our research is to verify to what stage intangible assets process is developed in Romanian local public administrations, the awareness and disclosure as well as the most influential factors in this disclosure.

Therefore, for the elaboration of this paper, we have defined the following objectives:

- To analyze the awareness of the importance of identification, measurement and disclosure of intangible assets in Romanian municipalities;

- To ascertain the extent of disclosure level of intangible assets in accordance with their measurement and recognition, relevant for the Romanian municipalities considered and

- To determine the most influential factors of intangible assets disclosure according to the national and international accounting standards applied in Romanian municipalities;

- To find out elements of voluntary disclosure in respect with full disclosure, measurement and recognition of intangible assets in Romanian municipalities.

Demonstrating the hypotheses arising from these objectives, we can find out the development stage in the process of disclosure, measurement and recognition of intangible assets in Romanian municipalities.

\subsection{Established Theories Related to the Present Research Purpose}

The disclosure of accounting information is based on social and politic theories. Out of them we remind the legitimacy theory and stakeholder theory.

According to the legitimacy theory, which emerged from the political process, the social disclosures can be viewed as a method of responding to the changing perceptions [37]. The regulatory bodies have the legitimacy to operate; the failure to comply with these regulations may increase the political costs and costs of information asymmetry. Therefore, the entities may have the incentive to disclose information to minimize these costs. One of the determinants analyzed in our work related to the legitimacy theory is visibility, which is a measure of the entity size, and openness on the financial market.

The notion of stakeholder theory as it originates and belongs to the private-sector entities sets out a possibility to be applied in public-sector framework also for either managerial decision making or organizations understanding and implementations [21]. The stakeholders' theory emphasizes the organizational responsibility in the disclosure of entities information for stakeholders concerning the most important activities, the main source of disclosure being through financial statements. The content analysis of local public administration reports by several stakeholders justifies the importance of this theory in our study.

\subsection{Sample Selection and Research Methodology}

Nowadays, in the technology era, the wealth created by the knowledge and intangible resources is seen mostly in larger towns with a high degree of urbanization, with a relatively large population and a major economic, social, political and cultural significance. Romania, as an European Member state, must comply with the Lisbon Strategy, as a process based on the management of knowledge and innovation intended to make the European Union the most competitive and dynamic economy in the world. In order to fulfil the international strategies, Romanian municipalities promoted numerous reforms for a better transparency, decision making and public information disclosure. One of the most important information in local public administration is that related to the intangible assets, as they represent the nucleus of the activities performed and services provided. In this respect, our research tries to find out the intangible assets measurement, recognition and disclosure stage of 104 Romanian municipalities' sample. In Romania, municipalities are defined as administrative units that fulfil minimal quantitative and qualitative criteria [27].

The research methodology is based on the content analysis technique, applied to all the 104 Romanian municipalities' annual reports, requested by mail or downloaded via municipalities' website. Moreover, 11 in-depth semi-structured interviews were performed with representatives of financial accounting department of Romanian municipalities in order to find out the awareness of the identification, measurement and disclosure of intangible assets. The data were collected during July-October 2013 for the 2012 annual report. 


\subsection{Variables Used, Data Processing and Results}

As regards the variables used, firstly we describe the dependent variable and then we define the independent variables considered appropriate for the development of this empirical study.

\section{Dependent variable}

The paper points out the disclosure index of intangible assets in the financial statements of 104 municipalities from Romania, taking as a reference the disclosure requirements stated in OMFP 1917, complemented with IPSAS 31, using the dichotomist procedure, where the value 1 is given if the local public administration discloses the issue in question and value 0 , if it does not. The score given to each item that composes the disclosure index is additive.

We share Cooke's idea [8] presented in numerous research papers in which entities that disclose the most important items also disclose the least important ones, the disclosure index of entities that do not disclose non-relevant items should not be penalized, arguing that if their report does not mention the disclosure of an item, it is concluded that this item was not relevant to the entity in that period. In the same way, if an item considered relevant was not disclosed it is clearly considered that there was no disclosure. Thus, the disclosure index is calculated for the application of the above mentioned by calculating the score of those elements disclosed or of those elements applicable. After establishing the disclosure index, a scoring sheet was developed to assess the extent of disclosure. If a municipality disclosed an item of information included in the index, it received a score of 1 , and 0 if it is not disclosed [8]. The method of computing the disclosure score for each municipality can be expressed as follows:

$$
\begin{aligned}
& \text { DIV 31=IA } A_{\text {OMFP1917 }}+C_{\mathrm{IA}_{\text {OMFP1917 }}^{\text {IA }}}^{\mathrm{A}_{\mathrm{OPSAS} 31}} \\
& \mathrm{IA}_{\text {OMFP1917 }}=\sum_{j=1}^{104} \frac{\alpha_{j}}{n} \\
& \mathrm{IA}_{\mathrm{IPSAS} 31}=\sum_{j=1}^{104} \frac{\beta_{j}}{p}
\end{aligned}
$$

where:

DIV 31 represents the total aggregate disclosure score;

IA OMFP1917 represents the aggregate disclosure score in accordance with OMFP 1917;

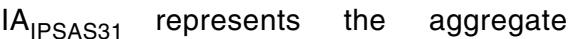
disclosure score in accordance with IPSAS 31;

$\mathrm{C}_{\text {IA }}^{\text {IA }_{\text {IPSASP1917 }}}$ represents the complement of aggregate disclosure score in accordance with OMFP 1917 on the aggregate disclosure score in accordance with IPSAS 31;

$\alpha_{i}$ is 1 if the jth item is disclosed or 0 if it is not disclosed in accordance with OMFP 1917 and $\mathrm{n}$ the maximum score each municipality can obtain in accordance with OMFP 1917;

$\beta_{\mathrm{j}}$ is 1 if the jth item is disclosed or 0 if it is not disclosed in accordance with IPSAS 31 and $p$ the maximum score each municipality can obtain in accordance with IPSAS 31.

In this case, the key fact is whether or not a municipality discloses an item of information in the annual report but does not analyze the disclosure quality of a specific item. It is noted that municipalities were not penalized for nondisclosure of an item if it was deemed to be irrelevant to its activities. For this purpose the entire annual report was read to assess the relevance of a particular item of information to the municipality.

\section{Independent variables}

The relationship between the dependent variable (DIV 31) and the independent variables (SIZE, ASS, PIBA, CLA, PQUOT) have been analyzed. The core paper which stays at this judgment is that of [43]. The general description and measurement of independent variables is presented in Tab. 4.

\section{SIZE (SIZE)}

The size is the most used variable in the literature about disclosure determinants and in most studies it explains the variability of the disclosures. It is seen from two points of view, as following:

a) Size as a measure of political and public visibility - Size is the proxy variable in political consideration [47]. Larger entities suffer of greater political pressure, and therefore, they increase their disclosure in 
Tab. 4: Independent variable description

\begin{tabular}{c|l|l} 
Independent variables & Description & Measurement \\
\hline SIZE & Size & Municipality size measured by the total inhabitants \\
\hline ASS & Assets & Logarithm of the asset value of the year for each municipality \\
\hline PIBA & $\begin{array}{l}\text { Percentage of intangibles } \\
\text { in the balance sheet }\end{array}$ & Measured by percentage of intangibles over total assets \\
\hline CLA & Intangible assets & $\begin{array}{l}\text { Number of intangible classes recognized according to } \\
\text { IPSAS 31 paragraph }\end{array}$ \\
\hline PQUOT & Publicly quoted & 1 for publicly quoted, 0 if not. \\
\hline
\end{tabular}

Source: own

order to reduce political costs [34]. Large entities attract greater interest or public visibility for financial statements users.

b) Size related to the production of information - Large entities, generally, use more sophisticated information systems, which allow disclosing more transparent information.

This variable has been measured in different ways in studies on intangible assets disclosure: logarithm of the asset value [9], [5] and municipalities number of inhabitants. Based on the theory, we state the following hypothesis: $\mathrm{H1}$ - There is a positive relationship between the municipality size and the disclosure of intangible assets in its financial statements.

\section{PERCENTAGE OF INTANGIBLE ASSETS (PIBA)}

This variable is used to study if a greater percentage in investments in intangible assets reported in the financial statements over total assets of a municipality encourages greater disclosure. This approach is described also in other studies [33]. Therefore, we can state the following hypothesis: $\mathrm{H} 2$ - The municipalities with the largest value of intangible assets accounted in their balance sheets show a higher disclosure index.

\section{CLASSES OF INTANGIBLE ASSETS (CLA)}

IPSAS 31 paragraph 118 establishes that public entities must disclose their intangible assets grouped by classes, defining a class of intangible assets as a grouping of assets of a similar nature and use in an entity's operations (paragraph 72). We complement the investment intensity level in intangible assets with the level of diversity. Therefore, in order to study the disclosure of intangible assets in the Romanian municipa- lities analyzed, we suppose that a greater variety of intangible assets can lead to a greater disclosure since a greater number of intangible assets classes could promote and provide wider and more varied information about them. On the basis of this evidence our third hypothesis is: H3 - The larger the number of intangible assets a municipality presents, the greater is the disclosure index of intangible assets.

An important indicator denoting economic and financial transparency is capital market trading. Therefore, we take into account in our study a dummy variable that reveals the extent to which municipalities perform traded transactions on the Bucharest Stock Exchange, The Romanian stock exchange where the municipalities trade municipal bonds: $\mathrm{H} 4-$ The disclosure index of intangible assets is bigger if the municipality is publicly quoted.

\section{Descriptive analysis of the data}

In order to analyze, interpret and carry out the statistic inference on the population sample, we describe in Tab. 5 the descriptive statistics of the quantitative variables.

As for the dummy variable included in this study, we found that $10.57 \%$ of municipalities are publicly quoted.

\section{Analysis of the results of the statistical tests}

In order to verify whether the variable PQUOT is statistically significant with the index DIV31, we preceded the Mann-Whitney test, which allowed us to verify the average disclosure in traded municipalities (Tab. 6). The test is not statistically significant $(p=0.716)$ for a level of error of 0.05 . 


\section{Finance}

\section{Tab. 5: Descriptive statistics of the quantitative variables}

\begin{tabular}{l|c|c|c|c|c} 
Elements & Sample size & Mean & Std. Deviation & Minimum & Maximum \\
\hline Disclosure index (DIV 31) & 104 & 0.2809 & 0.0581 & 0.1895 & 0.4793 \\
\hline Municipality size (population) & 104 & 76.542 & 0.5963 & 13.659 & 1883425 \\
\hline Logarithm of assets value & 104 & 12.0608 & 5.3643 & 3.087 & 26.092 \\
\hline Percentage of intangibles in the balance sheet & 104 & 0.5888 & 0.497 & 0.01 & 2.35 \\
\hline Classes of intangible assets presented & 104 & 1.12 & 0.416 & 1 & 7
\end{tabular}

Source: own

\section{Tab. 6: Mann-Whitney test for the variable Public quotation}

\begin{tabular}{l|c|c|c|c|c|c} 
DIV 31 & Values & N & Mean & Mann-Whitney & Z & Sig. \\
\hline \multirow{2}{*}{ Public quotation } & 0-no & 93 & 28.43 & \multirow{2}{*}{91.000} & \multirow{2}{*}{-2.5421} & 0.716 \\
\cline { 2 - 4 } & 1-yes & 11 & 36.00 & & & \\
\hline
\end{tabular}

Source: own

Supposing that a linear association exists between dependent variable and the set of independent variables, we perform the statistical model of multiple linear regression, explaining the behavior of the variable DIV31 according to the independent variables SIZE, ASS, PIBA, CLA and PQUOT.
Multiple linear regression model is the following:

DIV $31=\beta_{0}+\beta_{1}{ }^{*}$ SIZE $+\beta_{2}{ }^{*}$ ASS $+\beta_{3}{ }^{*}$ PIBA +

$+\beta_{4}{ }^{*} \mathrm{CLA}+\beta_{5}{ }^{*} \mathrm{PQUOT}+\delta$

Introducing all the independent variables in the multiple linear regression model, the data obtained are the following (Tab. 7):

\section{Tab. 7: Multiple linear regression}

\begin{tabular}{|c|c|c|c|c|}
\hline Var & $\beta$ & $t$ & sig & Results \\
\hline (constant) & 0.276 & 1.948 & 0.058 & \multirow{6}{*}{$\begin{array}{c}\mathrm{R}=0.683 \\
\mathrm{R}^{2}=0.468 \\
\text { R2Adjusted }^{2}=0.379 \\
\mathrm{~F}=6.820 \\
\mathrm{P}=0\end{array}$} \\
\hline SIZE & 0.083 & 4.624 & 0.000 & \\
\hline ASS & 0.007 & 3.540 & 0.002 & \\
\hline PIBA & 0.016 & 748 & 0.720 & \\
\hline CLA & 0.003 & 1.731 & 0.087 & \\
\hline PQUOT & $3.478 \mathrm{E}-5$ & 024 & 0.983 & \\
\hline
\end{tabular}

Source: own

The analysis allow us to conclude that the statistically significant variables obtained from the econometric model are the variable SIZE and ASS, the others being without significant relationship with the dependent variable, because the sig. value associated with them is higher than the significance level of $0.5(p>\alpha)$. In the regression model, the correlation coefficient $(R)$ is $68.3 \%$, which means a moderate association between the independent variables and the dependent variable. The coefficient of determination $\left(R^{2}\right)$ is 0.468 , i.e., the variation in the disclosure index is influenced by the variables SIZE and ASS in $37.9 \%$. Therefore these results validate the hypothesis formulated that the disclosure index is greater in larger municipalities $(\mathrm{H} 1)$ and the municipalities with the largest value of intangible assets show 
a higher disclosure index $(\mathrm{H} 2)$. This statement is verified by several other studies on disclosure of intangible assets [48], [2], [15].

From the in-depth semi-structured interviews performed with representatives of financial accounting department of Romanian municipalities we found out their awareness about the importance of identification, measurement and disclosure of intangible assets. It was unanimity stated that municipalities accounting practitioners must primary focus on improved reporting of intangibles in a more consistent and comprehensive way. Also new trainings should be welcome to help public sector practitioners to make the best use of intangible assets. Content analysis permitted us to state that there were identified no supplementary measurement ways of intangible assets voluntary disclosed.

\section{Conclusions}

Nowadays economies are becoming knowledge based: performance is moving from investment in physical assets to investment in intangible knowledge based assets such as R\&D, design, software, and human capital. For many entities investment in such intangibles could equals or exceeds their investment in tangibles such as buildings, office equipment, hardware, machines, and vehicles, if they are properly measured and recognized. Despite the intangibles significance, the present study reveals a low level of interest in their identification, measurement and disclosure in local public sector.

In spite of the accounting rules that establish generally accepted criteria regarding the measurement and evaluation of these intangible assets, subjective factors could come into play, permitting that their value to be manipulated easily, especially for so-called intellectual capital. Subjective evaluation and measurement could generate bad information to stakeholders that is a more significant problem than giving short information.

Besides the accounting approach which faces reticence, the paper pointed out a chronological evidence of the literature as regards both monetary and non-monetary measurement methods of intangible assets which were mostly transposed in the public sector from the private one.

The authors support the idea of three levels as regard the development stages in the process of measurement, recognition and disclosure of full intangible assets.

The paper deals with the analysis of the annual reports of Romanian municipalities to verify the compliance with the requirements of disclosure demanded by accounting rules on intangible assets held by these institutions. In order to do this, a disclosure index was created based on disclosure requirements as stated in IPSAS 31 - Intangible assets and by means of the content analysis technique, information was collected and the financial statements of 104 Romanian municipalities were analyzed.

The global index was obtained by the adding of the OMFP 1917 updated and complement of IPSAS 31 on OMFP 1917 updated items disclosed over the applicable items, resulting in a quantitative dependent variable whose values vary between 0 and 1 . The results obtained when the simple linear regression model was applied, confirm that the Size explained by the population number and the logarithm of assets are explanatory variables considered significant. These two combined present an explanatory power of $46.8 \%$ of the variation in the disclosure index. Thus, larger municipalities are associated with a greater disclosure of the items required by OMFP 1917 updated and IPSAS 31 . The results are compared with those of other studies performed generally in the private sector.

Through the in-depth semi-structured interviews performed we can conclude that municipalities accounting practitioners must primary focus on improved reporting of intangibles in a more consistent and comprehensive way, while they are aware of the intangible assets importance. In order to make the best use of intangible assets new trainings should be welcome to help public sector practitioners. The conclusion is that the intangible assets disclosure index reveals a value of $28.09 \%$, in Romanian municipalities being predominant the software class on the most disclosed intangible assets. Also we concluded that there were identified no supplementary measurement ways of intangible assets voluntary disclosed, although there are presented some characteristics related to intangible assets.

Therefore, we can state that the Romanian municipalities could be classified in the second development stage in the process of measurement, recognition and disclosure of full 
intangible assets.

While the most common reason for measuring and reporting the intangible assets is to improve internal performance, i.e. management control., the improvement of the measuring and disclosure of intangible assets is a goal. In the New Public Management Era we can state that the municipalities of the future need to have tools to monitor their progress, being the most effective agents of "mindware".

\section{References}

[1] AAA FINANCIAL ACCOUNTING STANDARDS COMMITTEE. Implications of Accounting Research for the FASB's Initiatives on Disclosure of Information about Intangible Assets. Accounting Horizons. 2003, Vol. 17, No. 2, pp. 175-185. ISSN 1558-7975.

[2] BOESSO, G., KUMAR, K. Drivers of corporate voluntary disclosure: A framework and empirical evidence from Italy and the United States. Accounting, Auditing \& Accountability Journal. 2007, Vol. 20, Iss. 2, pp. 269-296. ISSN 0951-3574.

[3] BONTIS, N., DRAGONETTI, N., JACOBSEN, K., ROOS, G. The Knowledge Toolbox: A review of the tools available to measure and manage intangible resources. European Management Journal. 1999, Vol. 17, No. 4, pp. 391-402. ISSN 0263-2373.

[4] BRADLEY, K. Intellectual capital and the new wealth of nations. Business Strategy Review. 1997, Vol. 8, Iss. 1, pp. 53-60. ISSN 1467-8616.

[5] BRÜGgeN, A., VERGAUWEN, P., DAO, M. Determinants of intellectual capital disclosure: evidence from Australia. Management Decision. 2009, Vol. 47, pp. 233-240. ISSN 0025-1747.

[6] CALU, D.A., PITULICE, I.C., DUMITRU, M., GORGAN, C. Empirical Survey Regarding the Presentation of General Purpose Financial Statements of the Public Sector Entities. Administraţie şi management public. 2008, No. 11, pp. 105-120. ISSN 1583-9583.

[7] CINCA, C.S., MOLINERO, C.M., BOSSI, Q.A. The measurement of intangible assets in public sector using scaling techniques. Journal of Intellectual Capital. 2003, Vol. 4, Iss. 2, pp. 249275. ISSN 1469-1930.

[8] COOKE, T.E. Disclosure in the Corporate Annual Reports of Swedish Companies. Accounting and Business Research. 1989, Vol. 19, Iss. 74, pp. 113-124. ISSN 0001-4788.

[9] CORMIER, D., AERTS, W., LEDOUX, M.J, MAGNAN, M. Attributes of social and human capital disclosure and information asymmetry between managers and investors. Canadian Journal of Administrative Sciences. 2009, Vol. 26, Iss. 1, pp. 71-88. ISSN 1936-4490.

[10] DUTZ, M.A., KANNEBLEY, J.S., SCARPELLI, M., SHARMA, S. Measuring intangible assets in an emerging market economy: An application to Brazil. Policy research working paper 6142 [online]. The Worldbank, c2012 [cit. 2013-10-20]. Available from: http://elibrary.worldbank.org/doi/ pdf/10.1596/1813-9450-6142.

[11] EDVINSSON, L., MALONE, M.S. Intellectual capital: Realizing your company's true value by finding its hidden brainpower. New York: Harper Business, 1997. ISBN 0-88730-841-4.

[12] EDVINSSON, L., STENFELT, C. Intellectual Capital of Nations - for Future Wealth Creation. Journal of Human Resource Costing \& Accounting. 1999, Vol. 4, Iss. 1, pp.21-33. ISSN 1401338X.

[13] ERNST\&YOUNG. A snapshot of GAAP differences between IPSAS and IFRS [online]. Ernst\&Young. 2013, April [cit. 2013-10-20]. 8 p. (PDF). Available from: http://www.ey.com/Pu blication/vwLUAssets/GAAP_differences_between _IPSAS_and_IFRS/\$FILE/IPSAS_vs_IFRS_AU1 506.pdf.

[14] GARCIA, J., ALONSO DE MAGDALENO, M.J. Fair value on commons-based intellectual property assets: Lessons of an estimation over Linux Kernel [online]. MPRA, c2010 [cit. 2013-10-20]. 25 p. (PDF). Available from: http://mpra.ub.unimuenchen.de/23680/1/MPRA_paper_23680.pdf.

[15] GERPOTT, T.J., THOMAS, S.E., HOFFMANN, A.P. Intangible asset disclosure in the telecommunications industry. Journal of Intellectual Capital. 2008, Vol. 9, Iss. 1, pp. 37-61. ISSN 1469-1930.

[16] HARRIS, I. A Theory of Intellectual Capital. Advances in Developing Human Resources. 2000, Vol. 2, No. 1, pp. 22-37. ISSN 1552-3055.

[17] IPSAS 31. Intangible assets [online]. IFRS Publications Departmen, c2010 [cit. 2013-10-26]. 55 p. (PDF). Available from: https://www.ifac.org/ sites/default/files/publications/files/ipsas-31intangible-assets-2.pdf.

[18] IPSASB Meeting. Conceptual Framework for General Purpose Financial Reporting by Public Sector Entities: Elements and Recognition on Financial Statements [online]. Toronto, 2013 [cit. 2013-10-20]. pp. 54 (PDF). Available from: www.ifac.org/sites/default/.../Agenda\%20items $\% 2$ 02A\%20combined.pdf. 
[19] ITTNER, C., LARCKER, D. Are non-financial measures leading indicators of financial performance? An analysis of customer satisfaction. Journal of Accounting Research. 1998, Vol. 36, pp. 1-35. ISSN 1475-679X.

[20] JOSE, M., UBHA, D.S., SIDHU, J.L. Disclosing intellectual capital in annual reports from Australian S/W \& I/T corporations. Journal of Knowledge Management Practice. 2010, Vol. 11, Iss. 3, pp. 1-19. ISSN 1705-9232.

[21] KENNEDY, T.M. Critical evaluation of the potential of stakeholder theory to contribute to understanding of large-scale public service IT projects and their implementation [online]. San Francisco (CA): Academia.edu, c2013 [cit. 2013-10-20]. 10 p. Available from: http://www.academia.edu/ 4249142/Critical_evaluation_of_the_potent ial_of_stakeholder_theory_to_contribute_to_unde rstanding_of_largescale_public_service_IT_ projects_and_their_implementation.

[22] KEONG, K. Intellectual capital: definitions, categorization and reporting models. Journal of Intellectual Capital. 2008, Vol. 9, Iss. 4, pp. 609638. ISSN 1469-1930.

[23] KONG, E., PRIOR, D. An intellectual capital perspective of competitive advantage in nonprofit organizations. International Journal of Nonprofit and Voluntary Sector Marketing. 2008, Vol. 13, Iss. 2, pp. 119-128. ISSN 1479-103X.

[24] KRSTIĆ, J., ĐORĐEVIĆ, M. Financial reporting on intangible assets: Scope and limitations. Facta universitatis. Series Economics and Organization. 2010, Vol. 7, No. 3, pp. 335-348. ISSN 0354-4699.

[25] LAMBERT, R.A. Customer satisfaction and future financial performance. Discussion of: Are nonfinancial measures leading indicators of financial performance? An analysis of customer satisfaction. Journal of Accounting Research. 1998, Vol. 36, pp. 37-46. ISSN 1475-679X.

[26] Law no. 215/2001 on local public administration, published in Official Gazette no. 204 of 23 April 2001, updated.

[27] Law no. 351/2001 on the approval of the National Spatial Plan - Section IV Network Places, published in Romanian Official Gazette, 6 July 2001.

[28] Law no. 500/2002 on Public Finance, published in Official Gazette no. 597 of 13.08.2002, updated.

[29] Law no. 52/2003 on transparency in public administration, published in Official Gazette no. 70 of 3 February 2003.
[30] Law no. 544/2001 on free access to public information, published in Official Gazette no. 663 of 23 October 2001, updated.

[31] MOURITSEN, J., THORBJØRNSEN, S., BUKH, P.N., JOHANSEN, M.R. Intellectual capital and new public management. The Learning Organisation. 2004, Vol. 11, Iss. 4/5, pp. 380-392. ISSN 0969-6474.

[32] NAVARRO, J.L.A., LÓPEZ, R.V.R., PEÑA, D.N. A theoretical intellectual capital model applied to cities. Amfiteatru economic. 2013, Vol. 19, Iss. 34, pp. 455-468. ISSN 2247-9104.

[33] OLLIER, C.B., CHAVENT, M., KUENTZ, V., WALLISER, E. L'adoption en France des norms IFRS relatives aux incorporels. Revue Française de Gestión. 2010, Vol. 207, pp. 93-110. ISSN 0338-455.

[34] OMOYE, S.A. Determinants of Intangibles Assets Disclosure in Annual Report: Evidence from Nigerian Quoted Companies. International Journal of Asian Social Science. 2013, Vol. 3, Iss. 5, pp. 1152-1165. ISSN 1911-2025.

[35] Order no. 1917/2005 approving the methodological norms regarding the organization and management of public institutions accounting, chart of accounts for public institutions and its implementing instructions, Document issued by the Ministry of Public Finance, published in Official Gazette no. 1186 of 29 December 2005, updated. [36] PETTY, R., GUTHRIE, J. Intellectual capital literature review: Measurement, reporting and management. Journal of Intellectual Capital. 2000, Vol. 1, Iss. 2, pp.155-176. ISSN 1469-1930.

[37] PRESTON, L.E., POST, J.E. Private Management and Public Policy. The Principle of Public Responsibility. Stanford University Press, 2012. ISBN 978-0804783866.

[38] RAMIREZ, Y. Intellectual capital models in Spanish public sector. Journal of Intellectual Capital. 2010, Vol. 11, Iss. 2, pp. 248-264. ISSN 1469-1930. [39] RAMíREZ, Y., TEJADA, Á., GORDILLO, S. Recognition of intellectual capital importance in the university sector. International Journal of Business and Social Research. 2013, Vol. 3, Iss. 4, pp. 27-41. ISSN 2164-2559.

[40] RHODES, R.A.W. Traditions and Public Sector Reform: Comparing Britain and Denmark. Scandinavian Political Studies. 1999, Vol. 22, Iss. 4, pp. 341-370. ISSN 1467-9477.

[41] ROSLENDER, R. Accounting for Intellectual Capital: Rethinking Its Theoretical Underpinnings. Measuring Business Excellence. 2004, Vol. 8, Iss. 1, pp. 38-45. ISSN 1368-3047. 


\section{Finance}

[42] SCHNIDER, A., SAMKIN G. Intellectual Capital reporting by the New Zeeland local government sector. Journal of Intellectual Capital. 2008, Vol. 9, Iss. 3, pp. 456-486. ISSN 1469-1930. [43] SILVA, M.L.R., RODRIGUES, A.M.G., MUÑOZ DUEÑAS, M.P. Disclosure of intangible assets: an empirical study of financial corporations in the Iberian Peninsula. Revistas Internacionais. Salerno, 2012. ISSN 1971-5293.

[44] STOLOWY, H., HALLER, A., International Accounting Disharmony: The Case of Intangibles. Accounting, Auditing \& Accountability Journal. 2001, Vol. 14, Iss. 4, pp. 477-497. ISSN 0951-3574. [45] SVEIBY, K.E. Methods for Measuring Intangible Assets [online]. Karl-Erik Sveiby, 2007 [cit. 2013-10-20]. Available from: http://www. sveiby.com/articles/ IntangibleMethods.htm.

[46] SVEIBY, K.E. The invisible balance sheet: key indicators for accounting, control and evaluation of know-how companies [online]. Stockholm: The Konrad Group, c1997 [cit. 2013-10-26]. 137 p. (PDF). Available from: www.sveiby.com/books/ DenOsynligaEng.pdf.

[47] WATTS, R.L., ZIMMERMAN, J.L. Positive Accounting Theory: A Ten Year Perspective. The Accounting Review. 1990, Vol. 65, Iss. 1, pp. 131156. ISSN 1558-7967.

[48] WHITE, G., LEE, A., TOWER, G., Drivers of voluntary intellectual capital disclosure in listed biotechnology companies. Journal of Intellectual Capital. 2007, Vol. 8, Iss. 3, pp. 517-537. ISSN 1469-1930.

[49] YARDIMCIOGLU, M. The Risks of Intangible Assets in Financial Statements. Allied Academies International Conference, Proceedings of the Academy of Accounting and Financial Studies. 2008, Vol. 13, No. 1, pp. 107-112. ISSN 1948-3147.
Assoc. Prof. Ovidiu Constantin Bunget, Ph.D.

West University of Timisoara

Faculty of Economics and Business

Administration,

Department of Accounting and Audit ovidiu.bunget@e-uvt.ro

Assoc. Prof. Rodica Gabriela Blidisel, Ph.D.

West University of Timisoara

Faculty of Economics and Business

Administration,

Department of Accounting and Audit rodica.blidisel@e-uvt.ro

Prof. Liliana Feleaga, Ph.D.

Bucharest University of Economic Studies

Faculty of Accounting and Management Information Systems

Department of Accounting and Audit Liliana.Feleaga@cig.ase.ro

Assoc. Prof. Irimie Emil Popa, Ph.D. Babes-Bolyai University of Cluj Napoca Faculty of Economics and Business Administration

Department of Accounting and Audit irimie.popa@econ.ubbcluj.ro 


\section{Abstract}

\section{EMPIRICAL STUDY OF INTANGIBLE ASSETS IN ROMANIAN MUNICIPALITIES \\ Ovidiu Constantin Bunget, Rodica Gabriela Blidisel, Liliana Feleaga, Irimie Emil Popa}

While economies are becoming more and more knowledge based, investment in intangibles assets becomes important tools for management if they are properly measured and recognized. While the literature states that the economic success is based on the effective utilization of intangible assets, in the public sector there is low level of interest in their identification, measurement and disclosure. In the light of the theoretical evidences, the purpose of our research is to verify the developed stage of intangible assets process in Romanian municipalities as regards the awareness, measurement and disclosure in 2012 annual reports. Also, the paper presents the most influential factors of intangible assets information disclosure. In order to do this, a disclosure index has been created, based on the requirements related to the intangible assets, taking into account the referential of Romanian regulations (OMFP 1917 updated) and International Public Sector Accounting Standards The research is based on content analysis and in-depth interviews methods for collecting data from the 104 Romanian municipalities. The analysis led to the conclusion that the disclosure index of intangible assets is 0.28 , where the municipality population and assets are the variables that are considered explanatory of the variation of the disclosure index in the regression analysis performed. There were identified no supplementary measurement ways of intangible assets voluntary disclosed, although the Romanian municipalities present some characteristics related to intangible assets. While management control is more and more important in local public administration, aiming to improve internal performance, the measurement and disclosure of intangible assets becomes a goal.

Key Words: Identification, measurement and disclosure of intangible assets, factors influencing the intangible assets disclosure.

JEL Classification: H11, H83, M41.

DOI: 10.15240/tul/001/2014-3-011 